\title{
THE RELATIONSHIP BETWEEN STUDENTS' CITIZENSHIP ACTIVITIES AND BULLYING AT SCHOOL
}

\author{
Ireta Čekse, Andrejs Geske, Kaspars Kiris \\ University of Latvia, Latvia
}

\begin{abstract}
School violence and bullying highlighted as a global issue outside and in the school. In this research, IEA International Civic and Citizenship Study (ICCS) 2016 data from eight countries - Finland, Estonia, Latvia, Lithuania, Germany (North Rhine-Westphalia), the Russian Federation, Sweden and Denmark - was compared. The aim of the article is to observe the relationship between bullying and students' citizenship activities at school and in the future. The research determined a relationship between bullying and factors that described students' citizenship activities. The results show that there is a link between bullying and students' experiences of participation in illegal and legal activities, participation in classroom discussions, interest in the wider community, and at-school citizenship activities. This article was supported by research application no. 1.1.1.2/VIAA/1/16/020, and European Social Fund project No. 8.3.6.2/17/I/001.
\end{abstract}

Keywords: attitudes, bullying, citizenship, civic education, ICCS 2016, students.

\section{Introduction}

\section{Bullying}

In the first decades of the $21^{\text {st }}$ century, bullying became one of the most important complications of the global world and education in general. Bullying has been defined as aggressive and violent behavior that can be identified through three criteria: it is repeated, intentional, and demonstrates power imbalance (Longobardi et al., 2020; Bochaver et al., 2019; Cosma et al., 2018). Bullying can be redefined into three traditional types physical, verbal and emotional - and in the latest decade, there appeared a new type named cyberbullying (Meszaros et al., 2020). The three traditional types of bullying can be divided by forms of acting: direct (verbal abuse and physical bullying) or indirect (ignoring, excluding, spreading rumors). Verbal and indirect bullying has been most prevalent in schools, as noticed by Australian students and teachers (Rigby, 2020). 
Cyberbullying is indicated as a growing type of violence over traditional bullying (Charalampous et al., 2021). There is evidence that cyberbullying might be categorized as a unique form of bullying (Williford \& DePaolis, 2019). It differs from traditional types of bullying due to its virtually limitless audience, the time and space over which violence can be spread, and the anonymity of the bullies (Selkie et al., 2016).

The gender factor appears to play a significant role in school bullying. Boys were more likely to be involved as bullies and victims in bullying and cyberbullying, while girls' participation was statistically significantly lower. Girls report significantly higher levels of post-traumatic symptoms in the event of bullying (Baldry et al., 2019). In some aspects of indirect bullying (spreading rumors), girls are more likely to be involved as bullies than boys (Geske et al., 2020).

\section{Bullying at the school}

Several authors (Mischel \& Kitsantas, 2020; Rønning et al., 2009) emphasize that it is very important to inform school staff and especially parents about bullying identification and programs to solve bullying-related problems in schools and in wider society. Improvements in the school climate lead to a reduction of bullying (Jia \& Konold, 2021) and lead to an open class climate. Regular measurements of bullying indicators must be provided in schools to indicate their appearance early on (Newgent et al., 2009). Teachers and medics must have a clear understanding of bullying behaviors, as they have a negative impact on children's mental and physical health (Fekkes et al., 2005). A large number of seminars must be provided and information disseminated on clear and practical methods to prevent and solve problems of bullying.

Students' inexperience of bullying is critical for their wellbeing and their achievements. It can have an impact on the school climate and create an environment that does not support students' development, openness and wish to participate in school life. To avoid bullying between students, some authors (Jenkins \& Canivez, 2021) have suggested discussing community building-related problems in the class. Discussions about compassion and the value of community-building can be a tool for teachers to identify students in the at-risk group of being bullied (Hart Barnett et al., 2019).

\section{Cyberbullying as upcoming problem}

Cyberbullying has differences from traditional bullying in circumstances, motivation and outcome. There are three characteristics (internet, repetition and power imbalance) that define cyberbullying (Englander et al., 2017). 
However, both traditional bullying and cyberbullying will continue to be significant problems for wider society. While conducting intervention and prevention programs against bullying, cultural values should be respected (Scheithauer et al., 2016). The most successful idea that focuses against violence and bullying is "No one should be unkind or hurtful" (Woolley, 2019). What has more influence than the curriculum are extracurricular activities, such as discussions with parents on civic, political and civically responsible activities ( $\mathrm{Li}, 2020)$. Parents are the most important actors in students' civic activities (Muddiman et al., 2019); moreover, the COVID-19 pandemic has undoubtedly changed teachers', students' and their parents' everyday lives across the globe. The "lockdowns" implemented the need for distance work and learning. Moving to the digital space increase threats of cyberbullying (Barlett et al., 2021). Nowadays, thoughts on the digital space and digital citizenship education come together with wonderings about cyberbullying, anxiety and burnout syndrome.

\section{School Climate and civic activities}

However, the school climate plays a significant role in students' wellbeing and, ultimately, life satisfaction (Aldridge et al., 2020). Further, class climate and attitudes against bullying affects a number of bullying cases (Košir et al., 2020; Thornberg et al., 2020). The external stressor of cyberbullying has the impact of negative attitudes toward school (Betts et al., 2017), but a positive attitude to peers and empathy help to improve victims' sense of safety in school (DeNike \& Gordon, 2020). The connection between school achievements and bullying is controversial and has been reported as a not dominating or impacting factor (Bilic et al., 2014). Others have found that academic achievements are connected with school results and classroom behavior in terms of bullies and victims (Gomes et al., 2020). There was some evidence for Grade 4 student achievements in Latvia during IEA PIRLS 2016. Researchers found a statistically significant relationship between students who have never been bullied and higher achievements in reading. A rising frequency of being bullied led to students having lower achievements in reading (Dedze \& Golubicka, 2020). A similar relationship between bullying and achievement is shown in the results of OECD PISA studies (Geske et al., 2020).

The results of Schihalejev et al. (2020) show that students from Estonia, Sweden and Finland believe that they are bullied because of otherness (clothes, friends, language, etc.). Also, a correlation was found between low belonging to school and the role of victims of bullies. In OECD PISA research (Geske et al., 2020), evidence is highlighted that students in Latvia feel they belong to their school less than OECD countries' average. The self-representation method may help the emotional rehabilitation of 
bullying victims in some cases (O'Brien \& Dadswell, 2020), but collaboration between schools and the wider environment will improve students' understanding of how school life relates to real life (Rauhansalo \& Kvieska, 2017). The results of another study (Lazar, 2013) show a significant connection between bullying and later antisocial behavior. Variables related to bullying are related to the current and future civic activities of students (including illegal activities) (Javornik et al., 2019). Being a bullying victim is a precondition for being a system outsider in future life (Bochaver et al., 2019). This factor makes an impression both on the student's young and adult life periods and can be a reason for radical civic activities.

However, civic education is multidisciplinary and needs to be integrated into every subject and extracurricular activity (Saveikaitè, 2014). Social actors and structures have direct links to civic processes (Haav, 2010). Every phenomenon in school today becomes a social phenomenon in adult life in later years. Now it is time to take care of our future. We understand that bullying has an influence on a broad number of life areas, but in this study, we focus on the relationship between bullying and students' citizenship activities at school and in the future. Accordingly, the research question of this article is: What is the relationship between bullying and factors that describe students' attitudes toward their country, perception of future citizenship activities, and perception of openness in the classroom and at school?

\section{Method}

For this research data from the IEA's International Civic and Citizenship Study (ICCS) 2016 (data available at https://doi.org/10.3886/ICPSR37147.v1) was used. The ICCS 2016 study is the fourth ICCS study. The aim of the study was to find out the ways in which young people are prepared to undertake their roles as citizens (Schulz et al., 2016).

In this article, the analyses use students' data from Finland ( $n=3173$, FIN), Estonia ( $n=2857$, EST), Latvia ( $n=3224$, LVA), Lithuania ( $n=3631$, LTU), Russia ( $n=7289$, RUS), Denmark ( $n=6254$, DNK), Sweden ( $n=3264$, SWE) and from the German state of North RhineWestphalia ( $n=1451$, DNW). All countries belong to the Baltic Sea region.

Bullying largely characterizes the school's microclimate; it seriously affects not only the victims and abusers but also other students. There are four types of bullying participants: bullies, victims, bullies/victims, non-bullies/non-victims (Cho et al., 2020). The aim of this article is to study the relationship between bullying and students' civic activities, but it should be noted that the impact of bullying is much broader. In Latvian schools, it is the second most important factor influencing the achievements of civic education after the socio-economic status of students. 
In this study, we use scales made up of individual items. This provides higher validity than using individual questions. The student bullying scale is made up of their answers to the question "During the last three months, how often did you experience the following situations at your school?" There were four possible answers - "Not at all," "Once," "Two to four times," and "Five times or more" - for each of the six situations - "A student called you by an offensive name," "A student said things about you to make others laugh," "A student threatened to hurt you," "You were physically attacked by another student," "A student broke something belonging to you on purpose," and "A student posted offensive pictures or text about you on the internet." Both this and other scales were calibrated with a mean value of 50 and a standard deviation of 10 . Higher values on the bullying scale indicate a higher level of abuse (Schulz et al., 2018).

\section{Results}

This analysis provides results from eight countries. The predictors describing bullying at school were divided into three groups. The first group describes students' attitudes toward their country, state institutions and individual responsibility (predictors: Students' positive attitudes toward their country of residence, Students' trust in civic institutions, Students' perception of the importance of personal responsibility for citizenship). The second group characterizes students' future citizenship activities (predictors: Students' perception of the importance of conventional citizenship, Students' expected electoral participation, Students' expected participation in illegal protest activities). The third group comprises students' attitudes toward the situation at school (predictors: Students' perception of openness in classroom discussions, Students' participation at school).

Table 1 shows the mutual correlations of these scales, which were calculated using the aggregated data of Latvian schools. The correlations can be seen to be positive (except for possible illegal activities) and mostly statistically significant with $95 \%$ confidence. This indicates that the students' current attitudes toward the state and its institutions, as well as their activity at school, form the model of their future activity as citizens.

Table 2 shows the correlations of bullying using the scales discussed above across the eight countries in the Baltic Sea region considered in this article. This restriction was chosen because these countries have much in common in terms of geographical location, past, present, and possible future. The lowest impact of bullying is in Lithuania and Finland, but this cannot be related to the frequency of abuse - this is highest in Lithuania but lowest in Finland. A strong impact of bullying is found in Russia, Germany and Denmark, and a medium impact in Latvia, Estonia and Sweden. 
Table 1. Mutual correlations of the scales at the school level in Latvia

\begin{tabular}{|c|c|c|c|c|c|c|c|c|c|}
\hline & Scale & 1 & 2 & 3 & 4 & 5 & 6 & 7 & 8 \\
\hline 1 & $\begin{array}{l}\text { Students' positive attitudes } \\
\text { toward their country of } \\
\text { residence }\end{array}$ & 1 & 0.42 & 0.40 & 0.44 & 0.32 & -0.03 & 0.12 & 0.21 \\
\hline 2 & $\begin{array}{l}\text { Students' trust in civic insti- } \\
\text { tutions }\end{array}$ & 0.42 & 1 & 0.58 & 0.47 & 0.48 & -0.14 & 0.35 & 0.35 \\
\hline 3 & $\begin{array}{l}\text { Students' perception of the } \\
\text { importance of personal re- } \\
\text { sponsibility for citizenship }\end{array}$ & 0.40 & 0.58 & 1 & 0.49 & 0.51 & -0.16 & 0.34 & 0.31 \\
\hline 4 & $\begin{array}{l}\text { Students' perception of the } \\
\text { importance of conventional } \\
\text { citizenship }\end{array}$ & 0.44 & 0.47 & 0.49 & 1 & 0.49 & 0.20 & 0.25 & 0.42 \\
\hline 5 & $\begin{array}{l}\text { Students' expected electoral } \\
\text { participation }\end{array}$ & 0.32 & 0.48 & 0.51 & 0.49 & 1 & -0.18 & 0.45 & 0.46 \\
\hline 6 & $\begin{array}{l}\text { Students' expected partic- } \\
\text { ipation in illegal protest } \\
\text { activities }\end{array}$ & -0.03 & -0.14 & -0.16 & 0.20 & -0.18 & 1 & -0.28 & 0.01 \\
\hline 7 & $\begin{array}{l}\text { Students' perception of open- } \\
\text { ness in classroom discussions }\end{array}$ & 0.12 & 0.35 & 0.34 & 0.25 & 0.45 & -0.28 & 1 & 0.44 \\
\hline 8 & $\begin{array}{l}\text { Students' participation at } \\
\text { school }\end{array}$ & 0.21 & 0.35 & 0.31 & 0.42 & 0.46 & 0.01 & 0.44 & 1 \\
\hline
\end{tabular}

Note. Figures in bold indicate a statistically significant correlation with $95 \%$ confidence.

Table 2. Correlation of bullying at the school level with students' opinions and possible civic activities

\begin{tabular}{|c|c|c|c|c|c|c|c|c|}
\hline & DNK & DNW & EST & FIN & LTU & LVA & RUS & SWE \\
\hline $\begin{array}{l}\text { Students' positive attitudes } \\
\text { toward their country of } \\
\text { residence }\end{array}$ & -0.28 & -0.14 & -0.22 & -0.12 & -0.04 & $\mid-0.31$ & -0.32 & -0.03 \\
\hline $\begin{array}{l}\text { Students' trust in civic } \\
\text { institutions }\end{array}$ & -0.39 & -0.38 & -0.24 & -0.19 & -0.10 & -0.09 & -0.44 & -0.40 \\
\hline $\begin{array}{l}\text { Students' perception of the } \\
\text { importance of personal re- } \\
\text { sponsibility for citizenship }\end{array}$ & -0.39 & -0.23 & -0.15 & -0.26 & -0.07 & $\mid-0.22$ & -0.31 & -0.36 \\
\hline $\begin{array}{l}\text { Students' perception of the } \\
\text { importance of conventional } \\
\text { citizenship }\end{array}$ & -0.25 & -0.34 & 0.02 & -0.04 & -0.08 & -0.15 & -0.32 & -0.16 \\
\hline $\begin{array}{l}\text { Students' expected elector- } \\
\text { al participation }\end{array}$ & -0.34 & -0.30 & -0.17 & -0.03 & 0.04 & $\mid-0.28$ & -0.37 & $\mid-0.31$ \\
\hline $\begin{array}{l}\text { Students' expected partic- } \\
\text { ipation in illegal protest } \\
\text { activities }\end{array}$ & 0.41 & 0.25 & 0.36 & 0.24 & 0.12 & 0.35 & 0.24 & 0.19 \\
\hline $\begin{array}{l}\text { Students' perception of } \\
\text { openness in classroom } \\
\text { discussions }\end{array}$ & -0.34 & -0.19 & -0.09 & -0.05 & -0.19 & $\mid-0.26$ & -0.43 & $\mid-0.32$ \\
\hline $\begin{array}{l}\text { Students' participation at } \\
\text { school }\end{array}$ & 0.00 & -0.43 & -0.17 & 0.17 & 0.00 & -0.21 & -0.32 & -0.03 \\
\hline
\end{tabular}

Note. Figures in bold indicate a statistically significant correlation with $95 \%$ confidence. 
The table shows that bullying is positively correlated with the possibility of students participating in illegal protest activities in the future. This could be explained by the victims' desire to do something similar to others. Bullying correlates negatively with other variables. Affected students have less positive attitudes toward their country of residence and civic institutions. It is also worth noting their lower self-confidence, which is indicated by the negative correlation with the perception of the importance of personal responsibility for citizenship. Bullying victims are also less involved in classroom and school activities.

\section{Discussion}

The aim of the present article was to observe the relationship between bullying and students' citizenship activities at school and in the future. The aggregated eight Baltic Sea region countries' ICCS 2016 data at school level was used to look for an answer to the research question of the article, which was: What is the relationship between bullying and factors that describe students' attitudes toward their country, perception of future citizenship activities, and perception of openness in the classroom and school?

There is not much previous research on recognizing the relationship between bullying and citizenship-related issues. More often, attention has been paid to other issues, for example, gender differences, where the percentage of girls in the profile of victims of severe harassment was higher (Jiménez, 2019), achievement in general (Al-Raqqad et al., 2017), or reading skills (Turunen et al., 2021).

The results of this research showed anegative relationship between bullying and students' perception of future citizenship activities and openness in the classroom and school. Our observations also highlighted a positive correlation in the relationship between bullying and expected participation in illegal protest activities. We can assume that bullying has a strong relationship with potential illegal protest activities in the future. On the other hand, victims also can change their behavior and become aggressive, unaccountable, and have a tendency to take excessive risks (Kretschmer et al., 2017). In summary, our findings show that bullying has an impact on future citizenship activities and values. Students who have no or less experience with bullying show a positive attitude toward citizenship activities, participation in different levels of elections, and getting information before voting in the future.

The findings (Chiu et al., 2016) show that, in general, students' sense of belonging is related to their relationships in school and the teacher-student relationship. In this survey, all eight countries show that there are negative relationships between bullying and attitudes toward their country 
of residence. Again, bullying does not contribute to the formation of an open classroom climate for discussions. The most pronounced observers are in Denmark, Latvia, Russia and Sweden. Moreover, the student's involvement in the citizenship activities at the school (e. g. participation in school debates on similar activities, student councils or senior elections, etc.). This is especially common in Germany, Latvia and Russia. The greater social competence of students leads to better competence in solving interpersonal problems that might prevent students from an escalation of potential violence against him or her (Javornik et al., 2019).

Accordingly, we can conclude that a pleasant and friendly environment in the classroom and school is a precondition for powerful citizenship activities in the present and future. Our findings hold the idea that the environment has a significant role in students' development as good citizens, attitudes, behavior and activities. Moreover, previous evidence (Brown \& Taylor, 2008) supports the idea that school bullying has an adverse effect on human capital accumulation both at and beyond school, and the adverse influence of bullying on educational attainment remains during adulthood.

In conclusion, bullying is a current problem in both the physical and virtual learning environments and attention must be paid to possible threats of cyberbullying that can also be recognized outside school (Englander et al., 2017).

\section{Conclusions}

The research highlighted three mean results. First, negative relationship between bullying and students' perception of future citizenship activities and openness in the classroom and school. Second, results show that bullying has an impact on future citizenship activities and values. Finally, findings show that students who have no or less experience with bullying show a positive attitude towards citizenship activities, participation in different levels of elections, and getting information before voting in the future.

Research in bullying needs to be continued, nevertheless, as the issue of bullying has broad and deep problems both inside and outside schools, and this has an impact on both students' development and the wellbeing of society.

\section{References}

Aldridge, J. M., McChesney, K., \& Afari, E. (2020). Associations between school climate and student life satisfaction: resilience and bullying as mediating factors. Learning Environments Research, 23(1), 129-150. https://doi.org/10.1007/s10984-019-09296-9

Al-Raqqad, H. K., Al-Bourini, E. S., Al Talahin, F. M. \& Aranki, R. M. E. (2017). The Impact of School Bullying On Students' Academic Achievement from Teachers Point of View. International Education Studies, 10(6), 44-50. https://doi.org/10.5539/ies.v10n6p44 
Baldry, A. C., Sorrentino, A., \& Farrington, D. P. (2019). Post-Traumatic Stress Symptoms Among Italian Preadolescents Involved in School and Cyber Bullying and Victimization. Journal of Child and Family Studies, 28, 2358-2364. https://doi.org/10.1007/ s10826-018-1122-4

Barlett, C. P, Rinker, A., \& Roth, B. (2021). Cyberbullying perpetration in the COVID-19 era: An application of general strain theory. The Journal of Social Psychology, 1-11. https://doi-org.datubazes.lanet.lv/10.1080/00224545.2021.1883503

Betts, L., Spenser, K. \& Gardner, S. (2017). Adolescents' Involvement in Cyber Bullying and Perceptions of School: The Importance of Perceived Peer Acceptance for Female Adolescents. Sex Roles, 77(7-8), 471-481. https://doi.org/10.1007/s11199-017-0742-2

Bilic, V., Flander, G. B., \& Rafajac, B. (2014) Life satisfaction and school performance of children exposed to classic and cyber peer bullying. Collegium Antropologicum, 38(1), 21-29.

Bochaver, A. A., Kuznetsova, V. B., Bianki, Y. M., Dmitrievsky, P. V., Zavalishina, M. A., Kaporskaya, N. A., \& Khlomov, K. D. (2019). The School Bullying Risk Survey. Russian Education \& Society, 61(1), 32-47. https://doi.org/10.1080/10609393.2019.1738784

Brown, S. \& Taylor, K. (2008). Bullying, education and earnings. Economics of Education Review, 27(4), 387-401.

Charalampous, K., Georgiou, S., Demetriou, C., Tricha, L., Nikiforou, M., \& Stavrinides, P. (2021). Comparing short-term growth in traditional and cyber forms of bullying in early and mid-adolescent students. European Journal of Developmental Psychology, 18(3), 412428, DOI: $10.1080 / 17405629.2020 .1798754$

Chiu, M. M., Chow, B. W. Y, McBride, C., \& Mol, S. T. (2016). Students' sense of belonging at school in 41 countries: Cross-cultural variability. Journal of Cross-cultural Psychology, 47(2), 175-196.

Cho, J., Hendrickson, J. M., \& Yi, H. (2020). Cross-informant Agreement on Bullying and Victimization of Middle School Students with and without Behavioral Disorders. Mid-Western Educational Researcher, 32(2), 88-106.

Cosma, A., Balazsi, R. \& Baban, A. (2018). Bullying, victimization and internalizing problems in school aged children: A longitudinal approach. Cognition, Brain, Behavior. An Interdisciplinary Journal, 22, 31-45. doi:10.24193/cbb.2018.22.03

Dedze, I., \& Golubicka, V. (2020). Agresija, pāridarījumi un emocionālā vide sākumskolā un to ietekme uz lasitprasmes sasniegumiem [Aggression, Harassment and the Emotional Environment in Primary School and their Impact on Literacy Achievement]. Izglitibas pētnieciba Latvijā/ [Education research in Latvia], 10, 101-130.

DeNike, M. \& Gordon, H. (2020). Solution Team: Outcomes of a Target-Centered Approach to Resolving School Bullying. Contemporary School Psychology, 24, 181-195. https://doi.org/10.1007/s40688-019-00234-3

Englander, E., Donnerstein, E., Kowalski, R., Lin, C. \& Parti, K. (2017). Defining Cyberbullying. Pediatrics, 140(S2), S148-S151. https://doi.org/10.1542/peds.2016-1758U

Fekkes, M., Pijpers, F. I. M., \& Verloove-Vanhorick, S. P. (2005). Bullying: who does what, when and where? Involvement of children, teachers and parents in bullying behavior, Health Education Research, 20(1), 81-91. https://doi.org/10.1093/her/cyg100

Geske, A., Grīnfelds, A., Kangro, A., Kiseḷova, R., \& Stūre, B. (2020). Latvijas skolēnu sasniegumi un skolas vide OECD PISA salīdzinājumā. [Latvian Students' Achievements and School Environment in OECD PISA Comparison], Izglītības pētniecība Latvijā [Educational Research in Latvia], 11. 
Gomes, A. M., Martins, M. C., Farinha, M., Silva, B., Ferreira, E., Caldas, A. C., \& Brandão, T. (2020). Bullying's Negative Effect on Academic Achievement. International Journal of Educational Psychology, 9(3), 243-268. https://doi.org/10.17583/ijep.2020.4812

Haav, K. (2010). Education for Democratic Citizenship: Development of the Theoretical Framework for Estonia and EU. Proceedings of the Institute for European Studies, Tallinn University of Technology, No. 7.

Hart Barnett, J. E., Fisher, K. W., O'Connell, N., \& Franco, K. (2019). Promoting upstander behavior to address bullying in schools. Middle School Journal, 50(1), 6-11. https://doi.org/ 10.1080/00940771.2018.1550377

Javornik, Š., Mirazchiyski, P., \& Širca, N.T. (2019). Bullying of eighth graders in Slovenian primary schools (Secondary analysis of ICCS 2016). Solsko Polje, 30(5/6), 79-97. https://doi.org/10.32320/1581-6044.30(5-6)79-97

Jenkins, L. N. \& Canivez, G. L. (2021) Hierarchical factor structure of the Bullying Participant Behavior Questionnaire with a middle school sample. International Journal of School \& Educational Psychology, 9(1), 55-72, doi:10.1080/21683603.2019.1636734

Jia, Y. \& Konold, T. (2021) Moving to the Next Level: Doubly Latent Multilevel Mediation Models with a School Climate Illustration. The Journal of Experimental Education, 89(2), 422-440. doi:10.1080/00220973.2019.1675136

Jiménez, R. (2019). Multiple Victimization (Bullying and Cyberbullying) in Primary Education in Spain from a Gender Perspective. Multidisciplinary Journal of Educational Research, 9(2), 169-193.

Košir, K., Klasinc, L., Špes, T., Pivec, T., Cankar, G, \& Horvat, M. (2020). Predictors of self-reported and peer-reported victimization and bullying behavior in early adolescents: the role of school, classroom, and individual factors. European Journal of Psychology of Education, 35, 381-402. https://doi.org/10.1007/s10212-019-00430-y

Kretschmer, T., Veenstra, R., Deković, M., \& Oldehinkel, A. J. (2017). Bullying development across adolescence, its antecedents, outcomes, and gender-specific patterns. Development and Psychopathology, 29(3), 941-955. doi:10.1017/S0954579416000596

Lazar, T. (2013). What Comes After Bullying? Today's Children Are Tomorrow's Parents, 36, 34-39.

Li, X. (2020). Rethinking youth policy model in Europe and its constituents: civic learning and civic engagement. Urban Research \& Practice, 13(1), 97-108. doi:10.1080/1753 5069.2019.1667135

Longobardi, C., Borello, L., Thornberg, R., \& Settanni, M. (2020). Empathy and defending behaviours in school bullying: The mediating role of motivation to defend victims. British Journal of Educational Psychology, 90(2), 473-486. https://doi.org/10.1111/bjep.12289

Meszaros, A., Goian, C., Vlaicu, F. L., \& Balauta, D.S. (2020). A Comparative Analysis between the Perceptions and Attitudes of Students in Two High Schools with Different Status Regarding the Phenomenon of Bullying in Schools. Journal Plus Education / Educatia Plus, 26(1), 308-325.

Mischel, J. \& Kitsantas, A. (2020). Middle school students' perceptions of school climate, bullying prevalence, and social support and coping. Social Psychology of Education, 23(1), 51-72. https://doi.org/10.1007/s11218-019-09522-5

Muddiman, E., Taylor, C., Power, S., \& Moles, K. (2019). Young people, family relationships and civic participation. Journal of Civil Society, 15(1), 82-98. doi:10.1080/17448 689.2018.1550903 
Newgent, R., Lounsbery, K. L., Keller, E. A., Baker, C. R., Cavell, T., \& Boughfman, E. M. (2009). Differential Perceptions of Bullying in the Schools: A Comparison of Student, Parent, Teacher, School Counselor, and Principal Reports. Journal of School Counseling, 7(38), EJ886153.

O'Brien, N. \& Dadswell, A. (2020). Reflections on a participatory research project exploring bullying and school self-exclusion: power dynamics, practicalities and partnership working. Pastoral Care in Education, 38(3), 208-229. doi:10.1080/02643944.2 020.1788126

Rauhansalo, T. \& Kvieska, V. (2017). Finnish Education System in Integrated Social Education Context. Socialinis ugdymas, 46, 24-39. doi:10.15823/su.2017.10

Rigby, K. (2020). Do teachers really underestimate the prevalence of bullying in schools? Social Psychology of Education, 23, 963-978. https://doi.org/10.1007/s11218020-09564-0

Rønning, J. A., Sourander, A., Kumpulainen, K., Tamminen, T., Niemelä, S., Moilanen, I., Helenius, H., Piha, J., \& Almqvist, F. (2009). Cross-informant agreement about bullying and victimization among eight-year-olds: whose information best predicts psychiatric caseness 10-15 years later? Social Psychiatry and Psychiatric Epidemiology, 44, 15-22. https://doi.org/10.1007/s00127-008-0395-0

Saveikaitè, J. (2014). The influence of civic education on young people in Lithuania. Social Education / Learners and Educators Competence Change, 1(37), 18-31.

Scheithauer, H., Smith, P. K., \& Muthanna, S. (2016). Cultural Issues in Bullying and Cyberbullying Among Children and Adolescents: Methodological Approaches for Comparative Research. International Journal of Developmental Science, 10, 3-8.

Schihalejev, O., Kuusisto, A., Vikdahl, L., \& Kallioniemi, A. (2020) Religion and children's perceptions of bullying in multicultural schools in Estonia, Finland and Sweden. Journal of Beliefs \& Values, 41(3), 371-384. doi:10.1080/13617672.2019.1686732

Schulz, W., Ainley, J. F., Losito, B., \& Agrusti, G. (2016). Assessment framework. Springer.

Schulz, W., Carstens R., Losito, B., \& Fraillon, J. (eds.). (2018). ICCS 2016 Technical Report. IEA International Civic and Citizenship Education Study 2016. IEA.

Selkie, E. M., Fales, J. L. \& Moreno, M. A. (2016). Cyberbullying Prevalence Among US Middle and High School-Aged Adolescents: A Systematic Review and Quality Assessment. The Journal of Adolescent Health, 58(2), 125-133. https://doi.org/10.1016/ j.jadohealth.2015.09.026

Thornberg, R., Wänström, L., Elmelid, R., Johansson, A., \& Mellander, E. (2020). Standing up for the victim or supporting the bully? Bystander responses and their associations with moral disengagement, defender self-efficacy, and collective efficacy. Social Psychology of Education, 23(3), 563-581. https://doi.org/10.1007/s11218-020-09549-z

Turunen, T., Poskiparta, E., Salmivalli, C., Niemi, P., \& Lerkkanen, M.K. (2021). Longitudinal associations between poor reading skills, bullying and victimization across the transition from elementary to middle school. PloS One, 16(3), E0249112.

Williford, A. \& DePaolis, K.J. (2019). Validation of a Cyber Bullying and Victimization Measure Among Elementary School-Aged Children. Child \& Adolescent Social Work Journal, 36(5), 557-570. https://doi.org/10.1007/s10560-018-0583-z

Woolley, R. (2019). Towards an inclusive understanding of bullying: identifying conceptions and practice in the primary school workforce. Educational Review, 71(6), 730-747. https://doi.org/10.1080/00131911.2018.1471666 